\title{
CD44v6 expression is related to mesenchymal phenotype and poor prognosis in patients with colorectal cancer
}

\author{
SEIYA SAITO, HIROHISA OKABE, MASAYUKI WATANABE, TAKATSUGU ISHIMOTO, MASAAKI IWATSUKI, \\ YOSHIFUMI BABA, YOUHEI TANAKA, JUNJI KURASHIGE, YUJI MIYAMOTO and HIDEO BABA
}

\author{
Department of Gastroenterological Surgery, Graduate School of Medical Sciences, \\ Kumamoto University, Kumamoto 860-8556, Japan
}

Received October 11, 2012; Accepted December 25, 2012

DOI: $10.3892 /$ or.2013.2273

\begin{abstract}
CD44 standard isoform (CD44s) is a cancer stem cell marker in many tumors, and is one of the CD44 isoforms. CD44v6 has been reported to correlate with tumor progression and poor prognosis in colorectal cancer. However, the relevance of CD44s and CD44v6 to epithelial-mesenchymal transition (EMT) remains unclear. Immunohistochemistry was performed to investigate the clinical importance of CD44s and CD44v6 and their relevance to EMT in 113 patients with stage II/III colorectal cancer treated by curative resection. The relevance of CD44v6 knockdown to the phenotype of colon cancer cells was examined using small interfering RNA (siRNA) specific for CD44v6 in vitro. CD44v6 expression showed a significant inverse correlation with E-cadherin expression $(\mathrm{P}=0.0007)$ and a positive correlation with vimentin expression $(\mathrm{P}=0.0096)$. A multivariate analysis showed that high CD44v6 expression was an independent poor prognostic factor for disease-free survival $(\mathrm{P}=0.01, \mathrm{HR}=3.05)$ and overall survival $(\mathrm{P}=0.025, \mathrm{HR}=3.16)$. The clinical significance and the relevance of $\mathrm{CD} 44 \mathrm{~s}$ expression to EMT markers was noted to a lesser extent compared to CD44v6 expression. The knockdown of CD44v6 decreased vimentin expression, cell invasion and HGF-induced cell migration, but conferred only a slight effect on E-cadherin expression in colon cancer cells (HCT116 and LoVo). CD44v6 is related to poor outcome of patients with colorectal cancer via upregulation of the mesenchymal phenotype.
\end{abstract}

Correspondence to: Professor Hideo Baba, Department of Gastroenterological Surgery, Graduate School of Medical Science, Kumamoto University, 1-1-1 Honjo, Kumamoto City, Kumamoto 860-8556, Japan

E-mail: hdobaba@kumamoto-u.ac.jp

Abbreviations: EMT, epithelial-mesenchymal transition; siRNA, small interfering RNA; RT-PCR, reverse transcription polymerase chain reaction; DFS, disease-free survival; OS, overall survival; HGF, hepatocyte growth factor; TGF- $\beta$, transforming growth factor- $\beta$; TNF $\alpha$, tumor necrosis factor $\alpha$

Key words: CD44v6, colorectal cancer, epithelial-mesenchymal transition

\section{Introduction}

Colorectal cancer is the third most commonly diagnosed cancer and the second leading cause of cancer-related death in the Western world $(1,2)$. Patients with early stage disease generally have an excellent prognosis after curative resection, while the prognosis for patients with distant metastases remains poor (3). Research has demonstrated that epithelialmesenchymal transition (EMT) plays a key role in the early process of the metastasis of cancer cells. EMT has been implicated in the development of invasive and metastatic tumor cells during tumor progression (4-6). This process involves the acquisition of the expression of mesenchymal molecules, such as vimentin and fibronectin, together with the loss of epithelial cell adhesion molecules such as E-cadherin (7).

CD44 is a cell adhesion molecule, which belong to a family of hyaluronan binding proteins. The smallest and most abundant isoform of CD44 is the so-called standard form (CD44s). The different isoforms are mainly generated by alternative splicing of 10 variant exons that account for sequences located in the extracellular part of the CD44 protein (8). Recently, CD44s has been considered to be one of the cancer stem cell markers in many solid tumors, including colorectal cancer $(9,10)$. CD44s can contribute to the activation of stem cell regulatory genes and can be a target of these genes (11). However, clinically, the value of CD44v6 rather than CD44s has been reported by many investigators as an immunohistochemical prognostic markers in colorectal cancer. Increased expression of CD44v6 has been reported in lymph node metastases, linked to adverse prognosis independent of Dukes' stage and UICC stage (12-16).

HGF-mediated activation of the c-Met tyrosine kinase pathway induces the proliferation, motility, adhesion and invasion of colon cancer cells (17-21). The HGF/c-Met pathway can contribute to EMT, including malignant tumor progression $(22,23)$. The activation of c-Met and the downstream signaling pathway to extracellular signal-regulated kinase (Erk) in response to HGF requires the presence of the CD44v6-containing isoform $(24,25)$.

A recent study reported that the hyaluronan-CD44 interaction plays a key role in EMT-associated fibrotic disorder (26). With regard to cancer progression and metastasis, the relevance of CD44s and/or CD44v6 to EMT is still poorly understood. 
In this study, we investigated whether CD44s and CD44v6 expression is associated with the EMT phenomenon in patients with colorectal cancer using immunohistochemistry and in vitro analysis.

\section{Materials and methods}

Patients and tissue samples. Among 166 patients with colorectal cancer who underwent curative surgery between 2000 and 2007 at the Department of Gastroenterological Surgery of the Kumamoto University Hospital, Kumamoto, Japan, we selected 113 patients diagnosed with stage II and III disease, according to the 7th edition of the UICC classification (27). None of the patients had undergone preoperative chemotherapy. Tissue specimens were collected from the patients after informed consent had been obtained, in accordance with the institutional guidelines of our hospital.

Cell lines and reagents. The human colon carcinoma cell line, LoVo, was purchased from Riken Bioresource Center (Osaka, Japan) and was cultured in Ham's F12 medium (Wako, Osaka, Japan). The HCT116 cell line was purchased from the ATCC (Manassas, VA, USA) and cultured in RPMI medium (Wako). All media were supplemented with $10 \%$ fetal bovine serum (Gibco, Tokyo, Japan), penicillin (100 units $/ \mathrm{ml}$ ), and streptomycin $(100 \mu \mathrm{g} / \mathrm{ml})$. All cells were incubated at $37^{\circ} \mathrm{C}$ in a humidified chamber supplemented with $5 \% \mathrm{CO}_{2}$. The anti-CD44s (clone, SFF-304) and CD44v6 (clone, VFF-18) antibodies were purchased from Bender MedSystems (Vienna, Austria). The antibodies against E-cadherin and fibronectin were purchased from BD-Biosciences (San Jose, CA, USA). The anti-vimentin antibody was purchased from Santa Cruz Biotechnology (Heidelberg, Germany). The anti- $\beta$-actin antibody was purchased from Cell Signaling Technology (Tokyo, Japan).

Immunohistochemical staining. The immunohistochemical procedure was performed as previously described (28). In brief, after deparaffinization and rehydration of $4-\mu \mathrm{m}$ sections, the endogenous peroxidase activity of the specimens was blocked with a methanol solution containing $3 \%$ hydrogen peroxide for $10 \mathrm{~min}$ at room temperature. Heat-induced antigen retrieval by microwave pretreatment in citrate buffer solution at $\mathrm{pH} 6.0$ (for E-cadherin) or $\mathrm{pH} 9.0$ (for CD44s, CD44v6 and vimentin) for 5-20 min was performed. Samples were incubated with the primary antibodies overnight at $4^{\circ} \mathrm{C}$ at the dilutions noted below. Anti-CD44s was used at a 1:100 dilution; anti-CD44v6 was used at 1:500; anti-E-cadherin was used at 1:1,200 and anti-vimentin was used at 1:50. A subsequent reaction was performed with the EnVision Plus detection system (Dako Co., Tokyo, Japan). A positive reaction was visualized with a diaminobenzidine solution, followed by counterstaining with Mayer's hematoxylin.

Evaluation and scoring. We randomly selected 5 fields within the tumor invasive front under high power magnification (x400) for evaluation. Each molecule expressed on cancer cells was quantified as a percentage of the total number of stained cells. For the expression of CD44s and CD44v6, we applied a three-grade scoring system of: i) strong, ii) moderate, or iii) weak/none. Strong staining was defined as staining in $>25 \%$ of the tumor cells, moderate staining was indicated when $<25 \%$ of the cells were stained, and staining in $<10 \%$ of the tumor cells or an absence of staining was scored as weak or none $(13,15)$. Both CD44s and CD44v6 were considered to be highly expressed when the staining was strong. For the expression of E-cadherin and vimentin, the median value of staining was determined to be the cut-off value. The immunostaining results were independently evaluated by two investigators who were blinded with respect to the clinical and histopathologic features.

Invasion assay. Cell invasion was assessed using the Matrigel invasion chamber (BD Biosciences, San Jose, CA, USA) as previously described (28). Cells (1x10 $/$ well) transfected with either negative-control siRNA $(200 \mathrm{nM})$ or CD44v6 siRNA (200 nM) were plated on Transwell chambers precoated with Matrigel in a 24-well plate. After the cells were incubated for $24 \mathrm{~h}$ at $37^{\circ} \mathrm{C}$ in a humidified incubator with $5 \% \mathrm{CO}_{2}$, the non-invading cells were removed with cotton swabs. The cells that had invaded through the membrane were fixed in $100 \%$ methanol and stained with toluidine blue. In five randomly selected fields, the number of invading cells was counted under a light microscope. Each experiment was performed in triplicate.

Wound healing assay. The migration activity was determined using the wound healing assay. A suspension of LoVo cells $\left(2.5 \times 10^{5} /\right.$ well $)$ was poured into each well using a 12 -well plate. After $24 \mathrm{~h}$ of incubation, the cells were transfected with siRNA and grown until subconfluence. The confluent cell layer was scratched with a pipette tip, followed by medium replacement with or without $50 \mathrm{ng} / \mathrm{ml}$ recombinant HGF (R\&D Systems, Minneapolis, MN, USA). The wound distances were measured and averaged from 5 points per wound area as a baseline width. After $24 \mathrm{~h}$, the width of the mean wound distance was calculated. To evaluate the 'wound closure', five randomly selected points along each wound were marked, and the horizontal distance the migrating cells traveled into the wound was measured. The data are reported as the means $\pm \mathrm{SD}$.

RNA extraction, cDNA synthesis and quantitative RT-PCR assay. Total RNA was obtained from the cell lines using the RNeasy Mini kit (Qiagen, Tokyo, Japan), according to the manufacturer's instructions. cDNA was synthesized with the SuperScript III Transcriptor First Strand cDNA Synthesis system for RT-PCR (Invitrogen, Tokyo, Japan), according to the manufacturer's instructions. Quantitative reverse transcription PCR (qRT-PCR) was performed using a LightCycler 480 II system (Roche Diagnostics, Tokyo, Japan) as previously described (29). To perform qPCR, primers were designed using the Roche Webpage and the Universal Probe Library following the manufacturer's recommendations. The primers used were as follows: CD44v6 forward, 5'-AACAGCTACCCA GAAGGAACAG-3'; CD44v6 reverse, 5'-CTTTGGGTGTTT GGCGATA-3'; and universal probe \#145; GAPDH forward, 5'-AGCCACATCGCTCAGACAC-3'; GAPDH reverse, 5'-GC CCAATACGACCAAATCC-3'; and universal probe \#60. For amplification, an initial denaturation at $95^{\circ} \mathrm{C}$ for $10 \mathrm{~min}$ was followed by $15 \mathrm{sec}$ at $95^{\circ} \mathrm{C}, 15 \mathrm{sec}$ at $60^{\circ} \mathrm{C}$, and $13 \mathrm{sec}$ at $72^{\circ} \mathrm{C}$. 
Table I. Expression levels of E-cadherin and vimentin compared to that of CD44v6.

\begin{tabular}{lcccc}
\hline & & \multicolumn{2}{c}{ CD44v6 } & \\
\cline { 3 - 4 } Molecule & $\begin{array}{c}\text { Total } \\
(\mathrm{n}=113)\end{array}$ & $\begin{array}{c}\text { High } \\
(\mathrm{n}=38)\end{array}$ & $\begin{array}{c}\text { Low } \\
(\mathrm{n}=75)\end{array}$ & P-value \\
\hline E-cadherin & & & & \\
High & 55 & 10 & 45 & 0.0007 \\
Low & 58 & 28 & 30 & \\
Vimentin & & & & \\
High & 55 & 25 & 30 & 0.0096 \\
Low & 58 & 13 & 45 & \\
\hline
\end{tabular}

All experiments were performed two times to confirm their reproducibility.

Western blot analysis. For isolating the proteins, cells harvested in 6-well plates were washed once in PBS and lysed in lysis buffer [Tris- $\mathrm{HCl}$ (pH 7.4), $25 \mathrm{mmol} / \mathrm{l}$; NaCl, $100 \mathrm{mmol} / \mathrm{l}$; EDTA, $2 \mathrm{mmol} / \mathrm{l}$; Triton X-100, 1\%; with $10 \mu \mathrm{g} / \mathrm{ml}$ aprotinin, $10 \mu \mathrm{g} / \mathrm{ml}$ leupeptin, $1 \mathrm{mmol} / 1 \mathrm{Na}_{3} \mathrm{VO}_{4}, 1 \mathrm{mmol} / 1$ phenylmethylsulfonyl fluoride]. Equal amounts of proteins were loaded onto $10 \%$ gels and were separated by SDS-PAGE. The resolved proteins were electrophoretically transferred to polyvinylidene fluoride (PVDF) membranes (Bio-Rad Laboratories, Hercules, CA, USA). The membranes were blocked with $5 \%$ low-fat dry milk in TBS-T [25 mM Tris (pH 7.4), $125 \mathrm{mM} \mathrm{NaCl,}$ $0.4 \%$ Tween 20] for $90 \mathrm{~min}$ at room temperature, followed by incubation with the primary antibody at $4^{\circ} \mathrm{C}$ overnight. The primary antibodies for CD44v6 (1:1,000), E-cadherin $(1: 2,000)$, and vimentin $(1: 1,000)$ were the same as used for immunohistochemistry. Primary antibody for fibronectin was used at 1:1,000. The membranes were extensively washed and incubated with a 1:2,000 dilution of HRP-conjugated secondary antibody (Santa Cruz Biotechnology) for $1 \mathrm{~h}$ at room temperature. The membranes were washed and visualized using the chemiluminescence detection reagent kit (ECL Plus; GE Healthcare Corp., Tokyo, Japan).

Small interfering RNA transfection. Two different sequences of small interfering RNA (siRNA) targeting human CD44v6 and negative control siRNA were purchased from Qiagen (Tokyo, Japan). The sequences of CD44v6 were as follows: CD44v6\#1 sense, 5'-GGCAACUCCUAGUAGUACATT-3' and antisense, 5'-UGUACUACUAGGAGUUGCCTG-3'; CD44v6\#2 sense, 5'-GAAGACUCCCAUUCGACAATT-3' and antisense, 5'-UUGUCGAAUGGGAGUCUUCTT-3'. The cells were transfected with the CD44v6-targeting siRNA or non-silencing siRNA using Lipofectamine 2000 reagent (Qiagen) according to the manufacturer's protocol.

Statistical analyses. Statistical analyses were performed using the StatView 5.0 software program (SAS Institute, Inc., Cary, NC, USA). The progression-free survival (PFS) and overall survival (OS) were calculated using the Kaplan-Meier method and the log-rank test was used to determine the statistical
Table II. Correlation between the CD44v6 expression pattern and clinicopathological factors of the colorectal cancer patients.

\begin{tabular}{|c|c|c|c|c|}
\hline \multirow[b]{2}{*}{$\begin{array}{l}\text { Clinicopathological } \\
\text { factors }\end{array}$} & \multirow[b]{2}{*}{$\begin{array}{c}\text { Total } \\
(\mathrm{n}=113)\end{array}$} & \multicolumn{2}{|c|}{ CD44v6 } & \multirow[b]{2}{*}{ P-value } \\
\hline & & $\begin{array}{l}\text { High } \\
(n=38)\end{array}$ & $\begin{array}{c}\text { Low } \\
(\mathrm{n}=75)\end{array}$ & \\
\hline \multicolumn{5}{|l|}{ Age $(\text { years })^{\mathrm{a}}$} \\
\hline$\leq 68$ & 54 & 14 & 40 & 0.10 \\
\hline$>68$ & 59 & 24 & 35 & \\
\hline \multicolumn{5}{|l|}{ Gender } \\
\hline Male & 62 & 20 & 42 & 0.73 \\
\hline Female & 51 & 18 & 33 & \\
\hline \multicolumn{5}{|c|}{ Location of primary tumor } \\
\hline Colon & 78 & 27 & 51 & 0.74 \\
\hline Rectum & 35 & 11 & 24 & \\
\hline \multicolumn{5}{|l|}{ Histological type } \\
\hline Well & 68 & 18 & 50 & 0.048 \\
\hline Other & 45 & 20 & 25 & \\
\hline \multicolumn{5}{|l|}{ Tumor size $(\mathrm{mm})^{\mathrm{a}}$} \\
\hline$\leq 50$ & 54 & 16 & 38 & 0.39 \\
\hline$>50$ & 59 & 22 & 37 & \\
\hline \multicolumn{5}{|l|}{ Lymphatic invasion $^{\mathrm{b}}$} \\
\hline Negative & 90 & 28 & 62 & 0.26 \\
\hline Positive & 23 & 10 & 13 & \\
\hline \multicolumn{5}{|l|}{ Venous invasion ${ }^{\mathrm{b}}$} \\
\hline Negative & 49 & 19 & 30 & 0.31 \\
\hline Positive & 64 & 19 & 45 & \\
\hline \multicolumn{5}{|l|}{ pT stage } \\
\hline $\mathrm{T} 1 / \mathrm{T} 2$ & 4 & 1 & 3 & 0.71 \\
\hline $\mathrm{T} 3 / \mathrm{T} 4$ & 109 & 37 & 72 & \\
\hline \multicolumn{5}{|l|}{ pN stage } \\
\hline NO & 68 & 21 & 47 & 0.45 \\
\hline $\mathrm{N} 1 / \mathrm{N} 2$ & 45 & 17 & 28 & \\
\hline
\end{tabular}

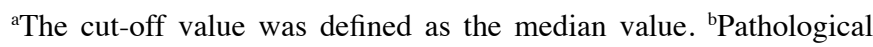
vascular invasion. Well, well-differentiated adenocarcinoma.

significance. A Cox proportional-hazards model was used to assess the risk ratio with simultaneous contribution from several covariates. Associations among discrete variables were assessed using the $\chi^{2}$ test. Mean values were compared using the Student's t-test. We analyzed the data by an ANOVA, followed by a Tukey-Kramer post-hoc test to compare multiple samples. P-values $<0.05$ were considered to indicate a statistically significant result.

\section{Results}

Relevance of CD44v6 and CD44s to EMT markers in patients with colorectal cancer. The expression of CD44s, CD44v6 and E-cadherin was observed on the membrane of cancer cells, while vimentin expression was observed in the cytoplasm. Although CD44s expression was noted in both 

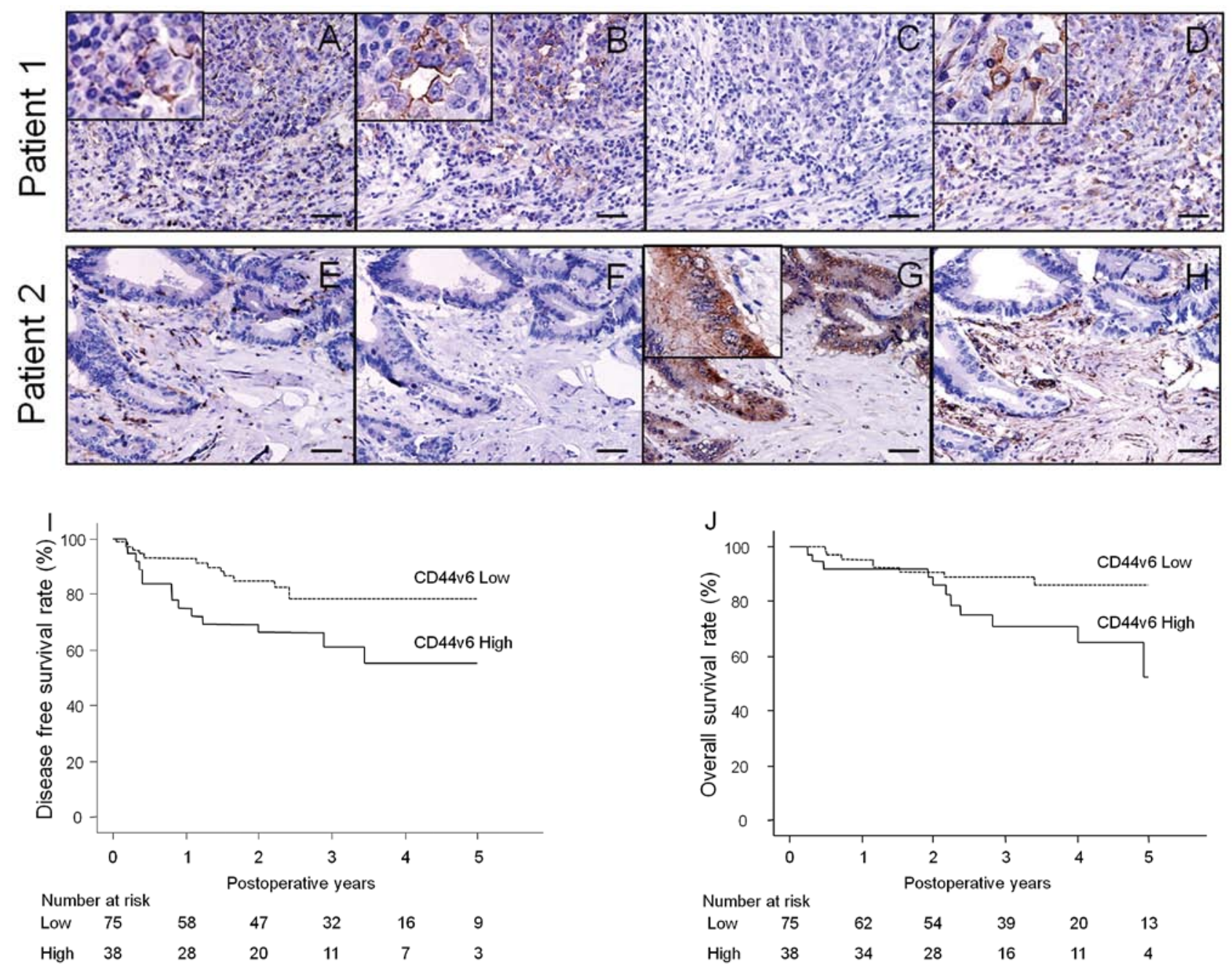

Figure 1. Clinical significance of CD44v6 and its relevance to EMT as evaluated by immunohistochemical analysis. Representative images of immunohistochemical staining using antibodies against CD44s (A and E), CD44v6 (B and F), E-cadherin (C and G), and vimentin (D and H) of specimens obtained from 2 patients with colorectal cancer. Patient 1 showed poorly differentiated cancer without E-cadherin expression. Patient 2 showed well-differentiated cancer with E-cadherin expression. Scale bar, $50 \mu \mathrm{m}$. Kaplan-Meier curves of the recurrence-free survival $(\mathrm{P}=0.010)(\mathrm{I})$ and overall survival $(\mathrm{P}=0.025)(\mathrm{J})$ of the patients according to CD44v6 expression.

cancer and stromal cells, such as fibroblasts and immune cells, CD44v6 expression was localized to the cancer cells. CD44v6 expression showed a significant inverse correlation with E-cadherin expression $(\mathrm{P}=0.0007)$ and a positive correlation with vimentin expression $(\mathrm{P}=0.0096)$ (Table $\mathrm{I})$, and the results from two representative patients are shown in Fig. 1A-H. In contrast, CD44s expression showed an inverse correlation with vimentin expression $(\mathrm{P}=0.031)$, and no correlation with E-cadherin expression (data not shown). High CD44s expression was not associated with a poor prognosis (data not shown). Based on these results, we examined the role of CD44v6 in EMT of colon cancer.

Clinicopathological features of patients and the impact of CD44v6 expression on the prognosis of stage II or III colorectal cancer. Table II shows the association between CD44v6 expression and the clinicopathological features of the 113 patients. A high level of CD44v6 expression was inversely correlated with histological differentiation of the tumor $(\mathrm{P}=0.048)$. To examine the prognostic value of CD44v6 expression, univariate and multivariate analyses were carried out (Table III). High CD44v6 expression was found to be an independent poor prognostic factor in disease-free survival (DFS) and overall survival (OS) (data not shown). Kaplan-Meier curves of the DFS and OS determined based on CD44v6 expression are shown in Fig. 1I and $\mathrm{J}(\mathrm{P}=0.03$ and $\mathrm{P}=0.047$, respectively).

Knockdown of CD44v6 results in the downregulation of mesenchymal markers. Since we hypothesized that CD44v6 has a role in the EMT phenomenon of colon cancer, we assessed whether CD44v6 knockdown impairs EMT in colon cancer cells. We transfected HCT116 and LoVo cells with two different siRNAs against CD44v6, and both reduced CD44v6 mRNA and protein expression compared with the control siRNA (Fig. 2A and B). We used siCD44v6\#1 in the subsequent experiments. Knockdown of CD44v6 downregulated the protein expression of vimentin and fibronectin when compared with the control, while little change was noted in E-cadherin expression (Fig. 2B). Vimentin expression in HCT116 cells and fibronectin expression in LoVo cells were too small to compare. 
Table III. Results of the univariate and multivariate analyses for disease-free survival.

\begin{tabular}{|c|c|c|c|c|c|c|c|}
\hline \multirow[b]{2}{*}{ Clinicopathological factors } & \multirow[b]{2}{*}{ Total $(n=113)$} & \multicolumn{3}{|c|}{ Univariate analysis } & \multicolumn{3}{|c|}{ Multivariate analysis } \\
\hline & & HR & $95 \% \mathrm{CI}$ & P-value & HR & $95 \%$ CI & P-value \\
\hline \multicolumn{8}{|l|}{ Age (years) ${ }^{\mathrm{a}}$} \\
\hline$\leq 68$ & 54 & 1.00 & $0.55-2.52$ & 0.67 & 1.00 & $0.74-4.11$ & 0.21 \\
\hline$>68$ & 59 & 1.18 & & & 1.74 & & \\
\hline \multicolumn{8}{|l|}{ Gender } \\
\hline Male & 62 & 1.00 & $0.49-2.21$ & 0.92 & 1.52 & $0.61-3.78$ & 0.37 \\
\hline Female & 51 & 1.04 & & & 1.00 & & \\
\hline \multicolumn{8}{|l|}{ Location of primary tumor } \\
\hline Colon & 78 & 1.00 & $0.90-4.11$ & 0.09 & 1.00 & $0.60-3.36$ & 0.43 \\
\hline Rectum & 35 & 1.92 & & & 1.41 & & \\
\hline \multicolumn{8}{|l|}{ Tumor size $(\mathrm{mm})^{\mathrm{a}}$} \\
\hline$\leq 50$ & 54 & 1.00 & $0.83-3.98$ & 0.13 & 1.00 & $0.68-3.57$ & 0.30 \\
\hline$>50$ & 59 & 1.82 & & & 1.56 & & \\
\hline \multicolumn{8}{|l|}{ Histological type } \\
\hline Well & 68 & 1.27 & $0.57-2.82$ & 0.56 & 3.03 & $1.09-8.46$ & 0.03 \\
\hline Other & 45 & 1.00 & & & 1.00 & & \\
\hline \multicolumn{8}{|l|}{ Lymphatic invasion $^{\mathrm{b}}$} \\
\hline Negative & 23 & 1.00 & $0.97-4.81$ & 0.06 & 1.00 & $0.98-8.98$ & 0.05 \\
\hline Positive & 90 & 2.15 & & & 2.97 & & \\
\hline \multicolumn{8}{|l|}{ Venous invasion ${ }^{\mathrm{b}}$} \\
\hline Negative & 64 & 1.00 & $0.63-3.04$ & 0.41 & 1.00 & $0.44-2.72$ & 0.85 \\
\hline Positive & 49 & 1.39 & & & 1.09 & & \\
\hline \multicolumn{8}{|l|}{ Invasion of primary tumor } \\
\hline Negative & 98 & 1.00 & $0.62-4.32$ & 0.32 & 1.00 & $0.78-7.16$ & 0.13 \\
\hline Positive & 15 & 1.63 & & & 2.36 & & \\
\hline \multicolumn{8}{|l|}{ Lymph node metastasis } \\
\hline Negative & 68 & 1.00 & $1.19-5.55$ & 0.02 & 1.00 & $1.26-7.54$ & 0.01 \\
\hline Positive & 45 & 2.57 & & & 3.08 & & \\
\hline \multicolumn{8}{|l|}{ CD44v6 } \\
\hline Low & 75 & 1.00 & $1.11-5.04$ & 0.03 & 1.00 & $1.31-7.07$ & 0.01 \\
\hline High & 38 & 2.37 & & & 3.05 & & \\
\hline
\end{tabular}

${ }^{a}$ The cut-off value was defined as the median value. ${ }^{b}$ Pathological vascular invasion. HR, hazard ratio; CI, confidence interval. Significance was set at $\mathrm{P}<0.05$. Well, well-differentiated adenocarcinoma.

Downregulation of CD44v6 decreases cancer cell invasion, migration and HGF-induced cell scattering. The Matrigel invasion assay revealed that the knockdown of CD44v6 decreased the invasive activity of HCT116 and LoVo cells (fold-changes were 0.34 and $0.50 ; \mathrm{P}=0.0003$ and 0.0001 ) (Fig. 2C). In addition, knockdown of CD44v6 inhibited the migration of HCT116 and LoVo cells (fold-changes, 0.54 and $0.34 ; \mathrm{P}=0.0085$ and 0.0094 , respectively) (Fig. 2D). The knockdown of CD44v6 did not cause any marked change in cell proliferation in either cell line (data not shown).

Based on previous reports indicating that CD44v6 induces cell scattering through HGF-cMet signaling in certain cancer cell cultures $(24,30)$, we examined whether CD44v6 mediates this phenomenon. HGF stimulation of the cancer cells for
$48 \mathrm{~h}$ led to an increase in cell migration (4.4-fold, $\mathrm{P}<0.0001)$ and CD44v6 knockdown decreased the HGF-mediated cell migration ( 0.55 -fold, $\mathrm{P}<0.05)$ (Fig. $2 \mathrm{E}$ ) in HCT116 cells. A similar effect was noted in LoVo cells, but the difference was not significant (data not shown). Taken together, these results indicate that CD44v6 supports HGF-induced cell scattering.

\section{Discussion}

The present study demonstrated that expression of CD44v6, but not CD44s, was highly correlated with the downregulation of E-cadherin and upregulation of vimentin expression in human samples, and CD44v6 supports the mesenchymal phenotype, such as cellular invasion, migration, HGF-induced 
A

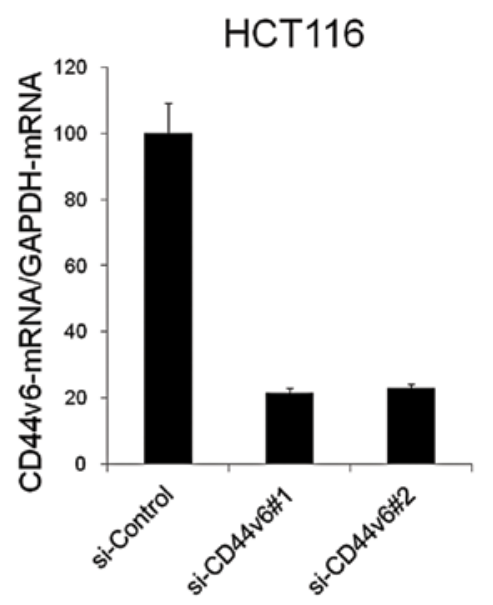

B

CD44v6

E-cadherin

Vimentin

Fibronectin

$\beta$-actin

$\mathbf{D}$
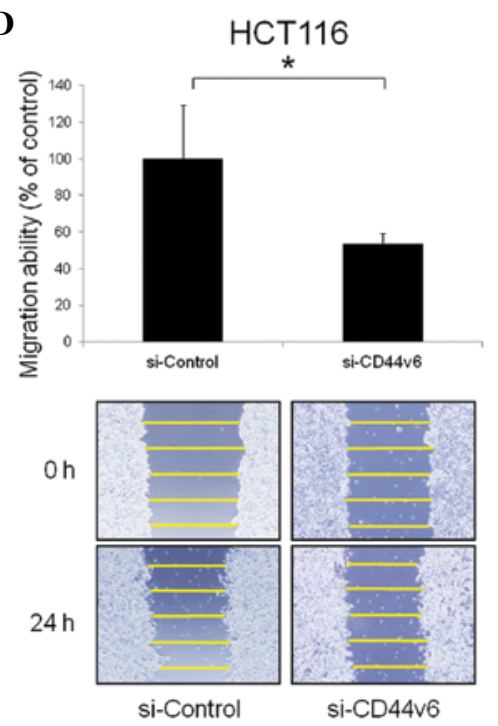

HCT116
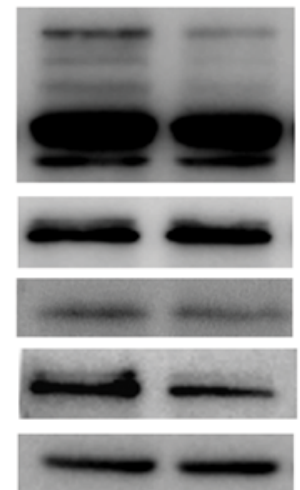
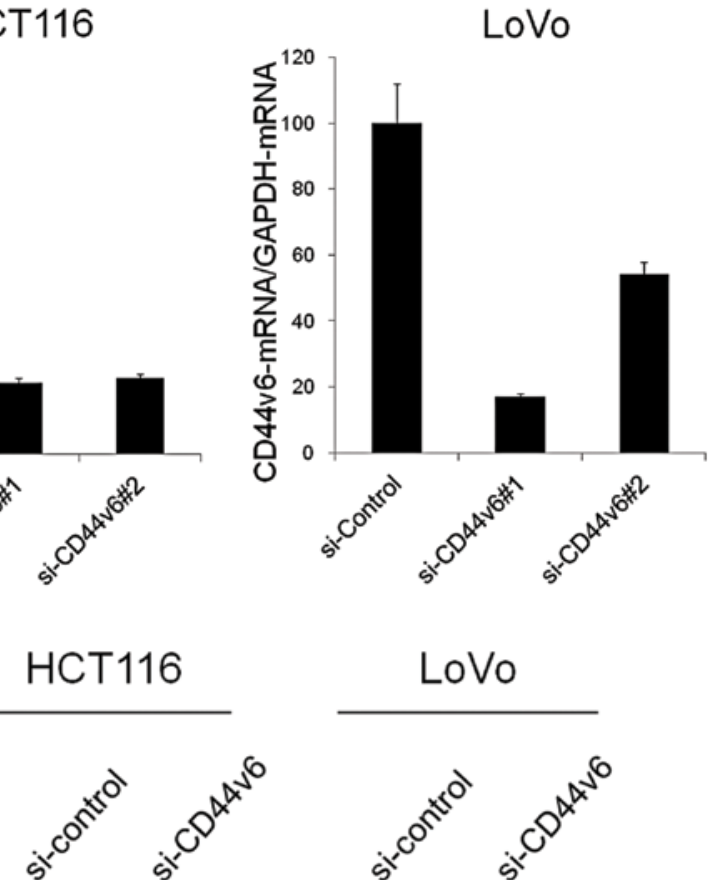

LoVo
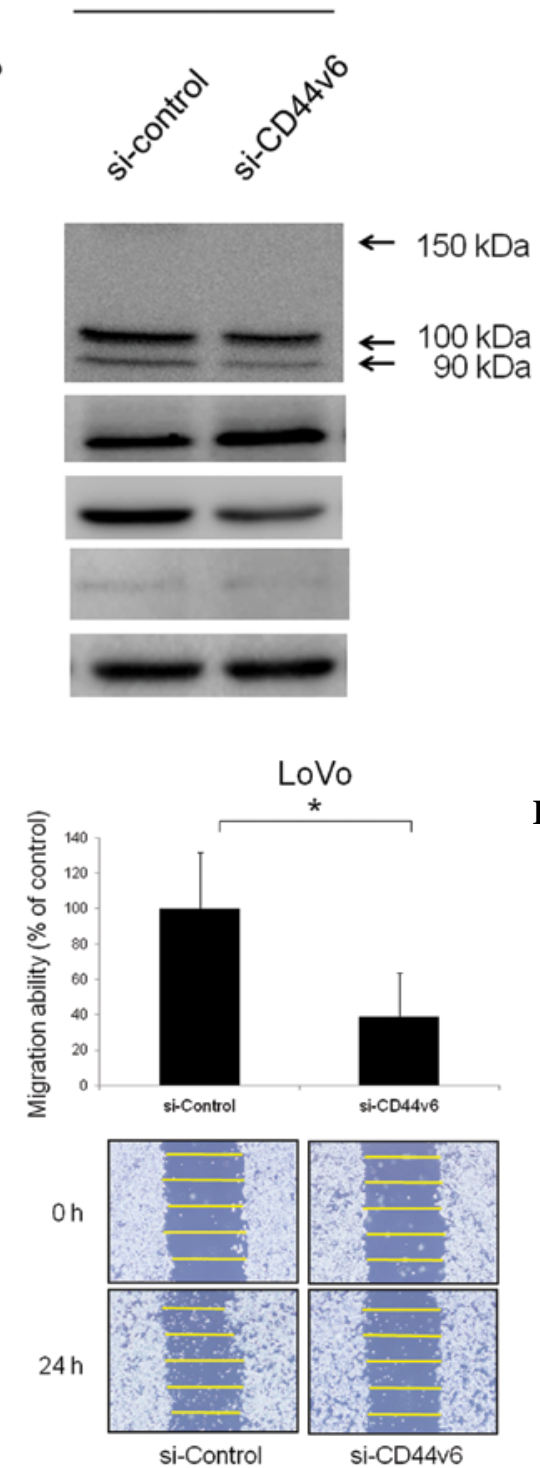

$\mathbf{E}$

C
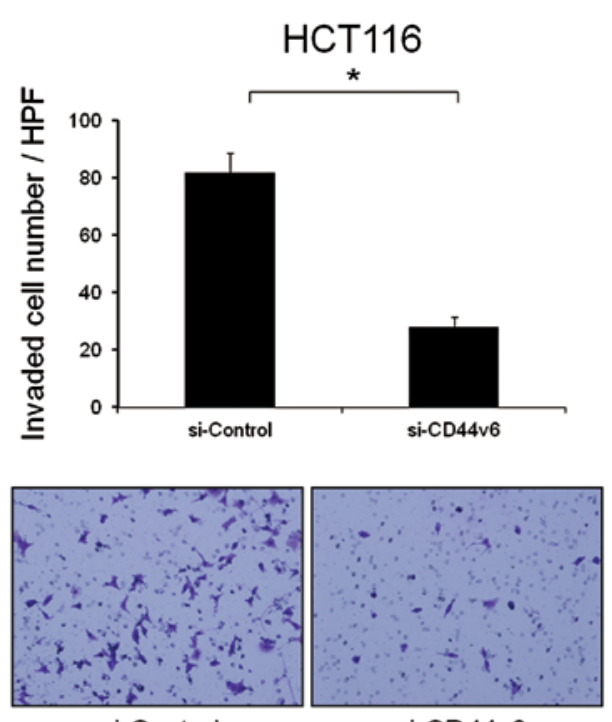

si-Control

si-CD44v6
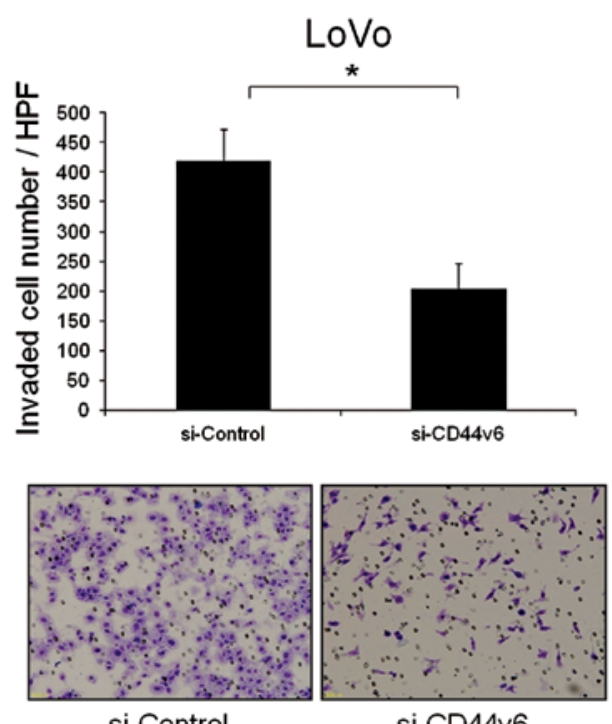

si-Control

si-CD44v6
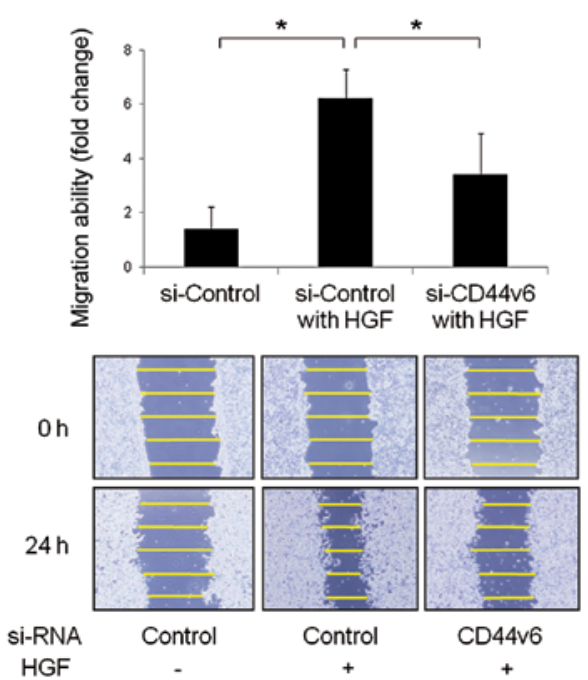

Figure 2. CD44v6 knockdown downregulates the mesenchymal phenotype. (A) Two different siRNAs downregulated the mRNA expression of CD44v6 in 2 different colon cancer cell lines in comparison to cells treated with the control siRNA. Bar, SD. (B) Western blot analysis showed that CD44v6 knockdown by CD44v6\#1-siRNA reduced the vimentin expression in LoVo cells and fibronectin expression in HCT116 cells, but only slightly affected the expression of E-cadherin in both cell lines. (C) CD44v6 knockdown reduced the invasive ability of both cell lines. HCT116 and LoVo cells were treated with siRNA for $48 \mathrm{~h}$ and were then used for the invasion assay. (D) CD44v6 knockdown reduced the migratory ability of both cell lines. HCT116 and LoVo cells were treated with siRNA for $48 \mathrm{~h}$ and then were used for the migration assay. (E) The HGF-induced cellular migration was evaluated by the wound healing assay. LoVo cells were treated with si-Control or si-CD44v6 for $48 \mathrm{~h}$, and were then stimulated with $50 \mathrm{ng} / \mathrm{ml}$ of HGF for $24 \mathrm{~h}\left({ }^{*} \mathrm{P}<0.05\right)$. 
Table IV. Summary of immunohistochemical-based studies for CD44v6 in colorectal cancer.

\begin{tabular}{|c|c|c|c|c|c|c|}
\hline Authors (ref.) & $\begin{array}{l}\text { Year } \\
\text { of study }\end{array}$ & $\begin{array}{l}\text { No. of } \\
\text { patients }\end{array}$ & Stage & Clone no. & Cut-off & $\begin{array}{l}\text { Effect of high CD } 44 v 6 \\
\text { expression on survival }\end{array}$ \\
\hline Mulder et al (13) & 1994 & 68 & Dukes' A-D & VFF4, 7 & $\begin{array}{l}(-)<10 \% \\
(+) 10-50 \% \\
(++)>50 \%\end{array}$ & Adverse effect \\
\hline Wielenga et al (15) & 1993 & 70 & Dukes' A-D & VFF4, 7 & $10 \%$ & Dukes' stage \\
\hline Finke et al (12) & 1995 & 102 & I-IV & VFF7 & $\begin{array}{l}(-) \quad 0, \\
(+) \leq 20 \%, \\
(+) 20-70 \%, \\
(++) \geq 70 \%\end{array}$ & UICC stage \\
\hline Koretz et al (43) & 1995 & 180 & Dukes' A-D & VFF7 & $10 \%$ & No effect \\
\hline Gotley et al (42) & 1996 & 109 & Dukes' A-D & $2 \mathrm{~F} 10,2 \mathrm{G} 9$ & & Not done \\
\hline Nanashima et al (39) & 1999 & 113 & $\begin{array}{l}\text { Dukes' B-D, } \\
\text { metastatic tumor }\end{array}$ & VFF7 & $(-),(+)$ & Favorable effect \\
\hline Neumayer et al (44) & 1999 & 81 & $\begin{array}{l}\text { Adenoma, carcinoma- } \\
\text { in-adenoma, } \mathrm{T} 1\end{array}$ & VFF7 & $10 \%$ & Not done \\
\hline Nanashima et al (38) & 2001 & 62 & Liver metastases & VFF7 & $10 \%$ & Favorable effect \\
\hline Günther et al (41) & 2002 & 116 & I-III & $2 \mathrm{~F} 10$ & $\begin{array}{l}(-) \quad<10 \%, \\
(+) 10-50 \%, \\
(++)>50 \%\end{array}$ & No effect \\
\hline Köbel et al (16) & 2004 & 145 & I-IV & VFF7 & $10 \%$ & Adverse effect \\
\hline Kuhn et al (45) & 2007 & 170 & I-IV & VFF18 & & No effect \\
\hline Peng et al (14) & 2008 & 179 & $\mathrm{II} / \mathrm{III}$ & VFF7 & $10 \%$ & Adverse effect \\
\hline Zlobec et al (40) & 2009 & 1,279 & I-IV, metastatic tumor & VFF18 & $30 \%$ & Favorable effect \\
\hline
\end{tabular}

cell scattering, and expression of mesenchymal markers, in colon cancer cells in vitro. Clinical research using immunohistochemistry also showed that a high level of CD44v6 expression was an independent prognostic factor for DFS and OS of stage II/III colorectal cancer patients following curative resection.

The levels of CD44s and CD44v6 expression in patients with colorectal cancer using immunohistochemical analysis remain controversial. Concerning CD44s, several studies have reported that CD44s expression is associated with an advanced stage of disease and a poor prognosis (31-34), whereas other studies found no significant correlation between CD44s expression and the progression of colorectal cancer patients $(35,36)$. Furthermore, the absence of CD44 expression in the stromal matrix was reported to be associated with a poor prognosis (37). Concerning CD44v6, its increased expression has been associated with poor prognosis, linked to adverse prognosis independent of Dukes' and UICC stages (12-16). However, others have reported that CD44v6 expression is associated with a favorable prognosis (38-40). Various clones of antibody, CD44s and CD44v6, appeared to affect the outcome of their clinical significance in patients with colorectal cancer. The clinical outcome and information regarding the antibodies used in previous reports are listed in Table IV.
Although many previous studies concerning CD44v6 in colon cancer have reported the significance of CD44v6 expression using immunohistochemistry-based prognostic studies (12-16,38-45), the effect of CD44v6 expression on EMT is unclear. This study suggests a molecular mechanism for how CD44v6 expression is linked to the malignant phenotype. The relationship of CD44v6 and EMT markers was particularly clear in the invasive front of colorectal cancer. In addition, we observed that a high level of CD44v6 expression was inversely correlated with cell differentiation. This result is consistent with previous studies $(46,47)$, and CD44v6 may be related to the phenotype of poorly differentiated cancer cells that is defined by a lack of cellular polarity and regularity.

To confirm these clinical observations, we examined the role of CD44v6 in colon cancer cells using RNA interference. The knockdown of CD44v6 decreased cell invasive and migratory capabilities, and also decreased vimentin expression, but had no obvious effect on E-cadherin expression in colon cancer cells. HGF/c-Met signaling and cell scattering were previously reported to be regulated by CD44v6 expression $(24,48)$, and we herein showed that CD44v6 expression was related to HGF-induced cell scattering. When this phenotypic change occurred, the E-cadherin expression level did not decrease after HGF treatment (data not shown). 
This study was limited with regard to how CD44v6expressing cells functionally differ from CD44s-expressing cells. A recent study indicated that the functional role of CD44s expression on breast cancer cells differed from that of a variant isoform in EMT regulation (49). Variant-specific functional roles have been identified not only for CD44v6, but also for CD44v3 in colorectal cancer $(21,50,51)$. Although our clinical outcome showed the relevance of CD44v6 to tumor progression and EMT phenomenon, further investigation is required to determine how the cellular phenotype is regulated under various microenvironmental conditions.

In conclusion, the clinical outcome suggests that CD44v6 but not CD44s is associated with E-cadherin downregulation and vimentin upregulation and thereby relates to tumor progression. In vitro analysis supported that CD44v6 may affect the mesenchymal phenotype of colon cancer cells.

\section{Acknowledgements}

We thank Keisuke Miyake, Naoko Yokoyama and Yuko Taniguchi for their technical assistance.

\section{References}

1. Ferlay J, Autier P, Boniol M, Heanue M, Colombet M and Boyle P: Estimates of the cancer incidence and mortality in Europe in 2006. Ann Oncol 18: 581-592, 2007.

2. Jemal A, Siegel R, Ward E, Murray T, Xu J and Thun MJ: Cancer statistics, 2007. CA Cancer J Clin 57: 43-66, 2007.

3. Dhar DK, Yoshimura H, Kinukawa N, et al: Metastatic lymph node size and colorectal cancer prognosis. J Am Coll Surg 200: 20-28, 2005.

4. Kalluri R: EMT: when epithelial cells decide to become mesenchymal-like cells. J Clin Invest 119: 1417-1419, 2009.

5. Thiery JP, Acloque H, Huang RY and Nieto MA: Epithelialmesenchymal transitions in development and disease. Cell 139: 871-890, 2009

6. Thiery JP: Epithelial-mesenchymal transitions in tumour progression. Nat Rev Cancer 2: 442-454, 2002.

7. Zeisberg M and Neilson EG: Biomarkers for epithelial-mesenchymal transitions. J Clin Invest 119: 1429-1437, 2009.

8. Ponta H, Sherman L and Herrlich PA: CD44: from adhesion molecules to signalling regulators. Nat Rev Mol Cell Biol 4: 33-45, 2003.

9. Al-Hajj M, Wicha MS, Benito-Hernandez A, Morrison SJ and Clarke MF: Prospective identification of tumorigenic breast cancer cells. Proc Natl Acad Sci USA 100: 3983-3988, 2003.

10. Dalerba P, Dylla SJ, Park IK, et al: Phenotypic characterization of human colorectal cancer stem cells. Proc Natl Acad Sci USA 104: 10158-10163, 2007.

11. Zoller M: CD44: can a cancer-initiating cell profit from an abundantly expressed molecule? Nat Rev Cancer 11: 254-267, 2011.

12. Finke LH, Terpe HJ, Zorb C, Haensch W and Schlag PM: Colorectal cancer prognosis and expression of exon-v6-containing CD44 proteins. Lancet 345: 583, 1995.

13. Mulder JW, Kruyt PM, Sewnath M, et al: Colorectal cancer prognosis and expression of exon-v6-containing CD44 proteins. Lancet 344: 1470-1472, 1994.

14. Peng J, Lu JJ, Zhu J, et al: Prediction of treatment outcome by CD44v6 after total mesorectal excision in locally advanced rectal cancer. Cancer J 14: 54-61, 2008.

15. Wielenga VJ, Heider KH, Offerhaus GJ, et al: Expression of CD44 variant proteins in human colorectal cancer is related to tumor progression. Cancer Res 53: 4754-4756, 1993.

16. Kobel M, Weichert W, Cruwell K, Schmitt WD, Lautenschlager C and Hauptmann S: Epithelial hyaluronic acid and CD44v6 are mutually involved in invasion of colorectal adenocarcinomas and linked to patient prognosis. Virchows Arch 445: 456-464, 2004.

17. Kammula US, Kuntz EJ, Francone TD, et al: Molecular co-expression of the c-Met oncogene and hepatocyte growth factor in primary colon cancer predicts tumor stage and clinical outcome. Cancer Lett 248: 219-228, 2007.
18. Jiang WG, Lloyds D, Puntis MC, Nakamura T and Hallett MB: Regulation of spreading and growth of colon cancer cells by hepatocyte growth factor. Clin Exp Metastasis 11: 235-242, 1993.

19. Uchiyama A, Essner R, Doi F, et al: Interleukin 4 inhibits hepatocyte growth factor-induced invasion and migration of colon carcinomas. J Cell Biochem 62: 443-453, 1996.

20. Di Renzo MF, Olivero M, Giacomini A, et al: Overexpression and amplification of the met/HGF receptor gene during the progression of colorectal cancer. Clin Cancer Res 1: 147-154, 1995.

21. Wielenga VJ, van der Voort R, Taher TE, et al: Expression of c-Met and heparan-sulfate proteoglycan forms of CD44 in colorectal cancer. Am J Pathol 157: 1563-1573, 2000.

22. Weidner KM, Sachs M and Birchmeier W: The Met receptor tyrosine kinase transduces motility, proliferation, and morphogenic signals of scatter factor/hepatocyte growth factor in epithelial cells. J Cell Biol 121: 145-154, 1993.

23. Bladt F, Riethmacher D, Isenmann S, Aguzzi A and Birchmeier C: Essential role for the c-met receptor in the migration of myogenic precursor cells into the limb bud. Nature 376: 768-771, 1995.

24. Orian-Rousseau V, Chen L, Sleeman JP, Herrlich P and Ponta H: CD44 is required for two consecutive steps in HGF/c-Met signaling. Genes Dev 16: 3074-3086, 2002.

25. van der Voort R, Taher TE, Wielenga VJ, et al: Heparan sulfatemodified CD44 promotes hepatocyte growth factor/scatter factor-induced signal transduction through the receptor tyrosine kinase c-Met. J Biol Chem 274: 6499-6506, 1999.

26. Takahashi E, Nagano O, Ishimoto T, et al: Tumor necrosis factoralpha regulates transforming growth factor-beta-dependent epithelial-mesenchymal transition by promoting hyaluronanCD44-moesin interaction. J Biol Chem 285: 4060-4073, 2010.

27. Edge SB Byrd BD and Compton CC: AJCC Cancer Staging Manual. 7th edition. Springer, New York, NY, 2010.

28. Okabe H, Beppu T, Hayashi H, et al: Hepatic stellate cells may relate to progression of intrahepatic cholangiocarcinoma. Ann Surg Oncol 16: 2555-2564, 2009.

29. Okabe H, Beppu T, Ueda M, Hayashi H, Ishiko T, Masuda T, Otao R, Horlad H, Mima K, Miyake K, Iwatsuki M, Baba Y, Takamori H, Jono H, Shinriki S, Ando Y and Baba H: Identification of CXCL5 involved in the interaction between cholangiocarcinoma and cancer associated fibroblasts. Int $\mathrm{J}$ Cancer 131: 2234-2241, 2012.

30. Grotegut S, von Schweinitz D, Christofori G and Lehembre F: Hepatocyte growth factor induces cell scattering through MAPK/Egr-1-mediated upregulation of Snail. EMBO J 25: 3534-3545, 2006.

31. Huh JW, Kim HR, Kim YJ, et al: Expression of standard CD44 in human colorectal carcinoma: association with prognosis. Pathol Int 59: 241-246, 2009.

32. Ichikawa W: Positive relationship between expression of CD44 and hepatic metastases in colorectal cancer. Pathobiology 62: 172-179, 1994.

33. Visca P, Del Nonno F, Botti C, et al: Role and prognostic significance of CD44s expression in colorectal cancer. Anticancer Res 22: 2671-2675, 2002.

34. Fernandez JC, Vizoso FJ, Corte MD, et al: CD44s expression in resectable colorectal carcinomas and surrounding mucosa. Cancer Invest 22: 878-885, 2004.

35. Heider KH, Hofmann M, Hors E, et al: A human homologue of the rat metastasis-associated variant of CD44 is expressed in colorectal carcinomas and adenomatous polyps. J Cell Biol 120: 227-233, 1993.

36. Ylagan LR, Scholes J and Demopoulos R: CD44: a marker of squamous differentiation in adenosquamous neoplasms. Arch Pathol Lab Med 124: 212-215, 2000.

37. Furuta K, Zahurak M, Goodman SN, Hamilton SR and August JT: CD44 expression in the stromal matrix of colorectal cancer: association with prognosis. Clin Cancer Res 4: 21-29, 1998.

38. Nanashima A, Yamaguchi H, Sawai T, et al: Prognostic factors in hepatic metastases of colorectal carcinoma: immunohistochemical analysis of tumor biological factors. Dig Dis Sci 46: 1623-1628, 2001.

39. Nanashima A, Yamaguchi H, Sawai $\mathrm{T}$, et al: Expression of adhesion molecules in hepatic metastases of colorectal carcinoma: relationship to primary tumours and prognosis after hepatic resection. J Gastroenterol Hepatol 14: 1004-1009, 1999. 
40. Zlobec I, Gunthert U, Tornillo L, et al: Systematic assessment of the prognostic impact of membranous CD44v6 protein expression in colorectal cancer. Histopathology 55: 564-575, 2009.

41. Gunther K, Dworak O, Remke S, et al: Prediction of distant metastases after curative surgery for rectal cancer. J Surg Res 103: 68-78, 2002.

42. Gotley DC, Fawcett J, Walsh MD, Reeder JA, Simmons DL and Antalis TM: Alternatively spliced variants of the cell adhesion molecule CD44 and tumour progression in colorectal cancer. $\mathrm{Br}$ J Cancer 74: 342-351, 1996.

43. Koretz K, Moller P, Lehnert T, Hinz U, Otto HF and Herfarth C: Effect of CD44v6 on survival in colorectal carcinoma. Lancet 345: 327-328, 1995.

44. Neumayer R, Rosen HR, Reiner A, et al: CD44 expression in benign and malignant colorectal polyps. Dis Colon Rectum 42: $50-55,1999$.

45. Kuhn S, Koch M, Nubel T, et al: A complex of EpCAM, claudin-7, CD44 variant isoforms, and tetraspanins promotes colorectal cancer progression. Mol Cancer Res 5: 553-567, 2007.

46. Liu YJ, Yan PS, Li J and Jia JF: Expression and significance of CD44s, CD44v6, and nm23 mRNA in human cancer. World J Gastroenterol 11: 6601-6606, 2005.
47. Bendardaf R, Elzagheid A, Lamlum H, Ristamaki R, Collan Y and Pyrhonen S: E-cadherin, CD44s and CD44v6 correlate with tumour differentiation in colorectal cancer. Oncol Rep 13: 831-835, 2005.

48. Tremmel M, Matzke A, Albrecht I, et al: A CD44v6 peptide reveals a role of CD44 in VEGFR-2 signaling and angiogenesis. Blood 114: 5236-5244, 2009.

49. Brown RL, Reinke LM, Damerow MS, et al: CD44 splice isoform switching in human and mouse epithelium is essential for epithelial-mesenchymal transition and breast cancer progression. J Clin Invest 121: 1064-1074, 2011.

50. Kuniyasu H, Oue N, Tsutsumi M, Tahara E and Yasui W: Heparan sulfate enhances invasion by human colon carcinoma cell lines through expression of CD44 variant exon 3. Clin Cancer Res 7: 4067-4072, 2001.

51. Yamaguchi A, Urano T, Goi T, et al: Expression of a CD44 variant containing exons 8 to 10 is a useful independent factor for the prediction of prognosis in colorectal cancer patients. J Clin Oncol 14: 1122-1127, 1996. 